\title{
Contribuições do PIBID Ciências da Natureza para o letramento científico na Educação Básica
}

\author{
Contributions of Nature Sciences PIBID for scientific lettering in Basic \\ Education
}

\section{Contribuciones del PIBID Ciencias de la Naturaleza para el letramento científico en la Educación Básica}

Ailton Jesus Dinardi ${ }^{1}$; Fernando Icaro Jorge Cunha ${ }^{2}$; João Victor Silveira Verçosa ${ }^{3}$; Alan Pedroso Leite ${ }^{4}$

\section{RESUMO}

O presente trabalho registra a inserção dos bolsistas do PIBID Ciências da Natureza em duas escolas públicas de Uruguaiana-RS e tem por objetivo analisar a importância das Feiras e Clubes de Ciências enquanto espaços de letramento científico e de protagonismo dos sujeitos envolvidos. Metodologicamente a pesquisa pode ser considerada uma pesquisa qualitativa que registra as ações e depoimentos no processo de organização de duas Feiras de Ciências (Escola A) e um Clube de Ciências (Escola B). Os resultados indicam que estes eventos são importantes espaços para a promoção do letramento científico e do protagonismo dos alunos. Os fundamentos que estruturam tal intervenção, buscam elucidar a importância de superar o Ensino de Ciências tradicional, obtendo como produto o letramento científico. Nas escolas supracitadas, a aplicação das Feiras e Clubes de Ciências, evidenciaram a riqueza de criatividade produzida pelos alunos, com a apresentação de diversos experimentos, discutidos de modo interdisciplinar entre todos os professores de Ciências da Natureza, demais áreas, bolsistas do PIBID, bem como, a supervisão e a coordenação do programa.

Palavras-chave: Ensino de Ciências; Experimentação; Formação Inicial e Continuada.

\begin{abstract}
This work reports the insertion of PIBID Sciences of Nature Scholarship holders in two public schools of Uruguaiana-RS city, and aims to analyze the importance of Science Fairs and Clubs as spaces of scientific literacy and protagonism of the individuals involved. Methodologically, the research can be considered as a qualitative research that records the actions and testimonies in the process of organizing two Science Fairs (School $A$ ) and a Science Club (School B). The results indicate that these events are important spaces for promotion of both scientific literacy and protagonism of students. The foundations that structure such intervention seek to elucidate the importance of overcoming traditional Science Teaching, obtaining scientific literacy as a result. In the aforementioned schools, the holding of Science Fairs and Clubs evidenced the richness of creativity produced by the students, with the presentation of several experiments, discussed in an interdisciplinary way among all Nature Science teachers, other areas teachers, and PIBID scholarship holders, as well as the supervision and coordination of the program.
\end{abstract}

Keywords: Science Teaching; Experimentation; Initial and Continuing Formation.

${ }^{1}$ Doutor em Ciência Florestal e Docente Permanente do PPG Educação em Ciências: Química da Vida e Saúde na Universidade Federal do Pampa (UNIPAMPA), Uruguaiana/RS - Brasil. E-mail: ailtondinardi@gmail.com

${ }^{2}$ Acadêmico do Curso de Licenciatura em Ciências da Natureza na Universidade Federal do Pampa, Uruguaiana/RS - Brasil. E-mail: icaro729@gmail.com

3 Acadêmico do Curso de Licenciatura em Ciências da Natureza na Universidade Federal do Pampa, Uruguaiana/RS - Brasil. E-mail: joaovercosa.aluno@unipampa.edu.br

${ }^{4}$ Acadêmico do Curso de Licenciatura em Ciências da Natureza na Universidade Federal do Pampa, Uruguaiana/RS - Brasil. E-mail: alanleite.aluno@unipampa.edu.br 


\section{RESUMEN}

El presente trabajo registra la inserción de becarios de Ciencias de la Naturaleza PIBID en dos escuelas públicas de Uruguaiana-RS y tiene como objetivo analizar la importancia de Ferias y Clubes de Ciencias como espacios de alfabetización científica y protagonismo de los sujetos involucrados. Metodológicamente, la investigación puede considerarse una investigación cualitativa que registra las acciones y testimonios en el proceso de organización de dos Ferias de Ciencias (Escuela A) y un Club de Ciencias (Escuela B). Los resultados indican que estos eventos son espacios importantes para la promoción de la alfabetización científica y el protagonismo de los estudiantes. Los fundamentos que estructuran dicha intervención buscan dilucidar la importancia de superar la Enseñanza de las Ciencias tradicional, obteniendo como producto la alfabetización científica. En las escuelas mencionadas, la aplicación de Ferias y Clubes de Ciencias evidenció la riqueza de creatividad producida por los estudiantes, con la presentación de varios experimentos, discutidos de manera interdisciplinaria entre todos los profesores de Ciencias de la Naturaleza, otras áreas, becarios PIBID, así como, la supervisión y coordinación del programa.

Palabras clave: Enseñanza de las ciencias; Experimentación; Formación inicial y continua.

\section{INTRODUÇÃO}

Segundo Silva (2016) as reformulações das orientações educacionais sobre o ensino de ciências vêm sendo propostas sob vários "slogans", os quais ressaltam a necessidade de se educar cientificamente os sujeitos para que se posicionem criticamente sobre assuntos científicos de interesse social. Sendo que:

O objetivo de formação para cidadania no de ensino de ciências se insere dentro do movimento de Letramento Científico. Letrar cientificamente os cidadãos é possibilitarIhes a compreensão de conhecimentos científicos básicos que os permitam ter uma leitura de mundo, ou seja, é habilitar os sujeitos para que façam uso da linguagem científica em seu contexto social, transformando-os em pessoas mais críticas que compreendam as inter-relações entre a Ciência, a Tecnologia, a Sociedade e o Ambiente (CTSA) (SILVA, 2016, p. 14).

Porém, como entrave a este processo de formação, pode-se inferir que a educação disponibilizada em nosso país por mais que tenha passado por reformulações no decorrer das décadas, fazendo o uso de uma visão mais ampla para o contexto educacional, possui um caráter tradicional, isto é, algo que segue impregnado na formação dos professores e na estrutura escolar. Sobre esse predomínio no ensino, destacamos as palavras de Saviani (1991, p.54) ao inferir sobre o sistema de ensino:

Esse ensino tradicional que ainda predomina hoje nas escolas se constituiu após a revolução industrial e se implantou nos chamados sistemas nacionais de ensino, configurando amplas redes oficiais, criadas a partir de meados do século passado, no momento em que, consolidado o poder burguês, aciona-se a escola redentora da humanidade, universal, gratuita e obrigatória como um instrumento de consolidação da ordem democrática (SAVIANI, 1991, p. 54).

Muitos docentes presentes nas escolas concluíram suas graduações e não procuraram por atualizações a respeito sobre novas metodologias de ensino, "O professor está desatualizado em relação à discussão sobre a educação, à profissão e seu papel social, escreve e lê pouco, tem uma enorme dependência do livro didático" (BRASIL, 2002, p. 32). Embora seja incorreto desqualificar o conhecimento e a experiência que estes profissionais adquiriram no decorrer do trabalho em sala de aula, é preciso reconhecer que as formas tradicionais são limitadas perante os educandos que são possuidores de inúmeras ferramentas eletrônicas, ferramentas as quais em alguns cliques ou toques Ihe dão informações. 
As salas de aula do século XXI por mais que tenham as mesmas cores de décadas atrás, organização de cadeiras e mesas, não possuem o mesmo público, os alunos de agora trazem para o convívio da sala de aula suas inquietações e por vezes não aceitam um mero despejo de conteúdo, que seu professor fale por todo um período e ele não possa se expressar. O docente por vezes está preso nas amarras do ensino tradicional, tal ensino não condiz com a forma de aprendizagem dos alunos. No passado a qualidade do ensino era comprovada tendo como base a quantidade de conteúdo passado, segundo Chassot (2003) "Não se escondia o quanto a transmissão (massiva) de conteúdos era o que importava. Um dos índices de eficiência de um professor - ou de um transmissor de conteúdos - era a quantidade de páginas repassadas aos estudantes - os receptores".

Como forma de enfrentamento e de melhorias no processo de ensino e aprendizagem de Ciências, o governo federal vem ofertando espaços de formação inicial e continuada que procuram contribuir com a interrupção deste ciclo vicioso. Dentre estes programas, encontra-se o Programa Institucional de Bolsa de Iniciação à Docência - PIBID que procura oportunizar a realização de projetos de iniciação à docência, tendo, como público-alvo, discentes que estejam na primeira metade dos cursos de licenciatura.

O PIBID dentre seus objetivos visa: elevar a qualidade da formação inicial de professores nos cursos de licenciatura, promovendo a integração entre Educação Superior e Educação Básica; proporcionar aos discentes, oportunidades de criação e participação em experiências metodológicas, tecnológicas e práticas docentes de caráter inovador e interdisciplinar que busquem a superação de problemas identificados no processo de ensino-aprendizagem.

Com relação ao ensino das ciências, especificamente, este deve ser realizado com a intenção de proporcionar aos estudantes uma leitura do mundo natural, pois segundo Chassot (2003) "O mundo é (existe) independente da ciência. Esta o torna inteligível, e a tecnologia, como aplicação da ciência, modifica esse mundo". A ciência possui uma linguagem própria e que por vezes dificulta e desmotiva os estudantes. Quando não há em sala de aula um espaço que possibilite uma troca de informações com um teor mais aprofundado a respeito de determinados assuntos, é importante que haja na escola locais ou eventos para que seja possível a realização dessa troca de informações.

Nesse interim, como forma de superação e de qualificação ao Ensino de Ciências e ao processo de formação docente, o planejamento e a organização de Clubes e Feiras de Ciências é importante, visto que, são atividades que precisam ser incentivadas e registradas como possibilidades de alfabetização e letramento científico, em concordância com a BNCC (Base Nacional Comum Curricular), que registra:

[...] ao longo do Ensino Fundamental, a área de Ciências da Natureza tem um compromisso com o desenvolvimento do letramento científico, que envolve a capacidade de compreender e interpretar o mundo (natural, social e tecnológico), mas também de transformá-lo com base nos aportes teóricos e processuais das ciências. Em outras palavras, apreender ciência não é a finalidade última do letramento, mas, sim, o desenvolvimento da capacidade de atuação no e sobre o mundo, importante ao exercício pleno da cidadania (BRASIL, 2018, p.321).

Os Clubes e Feiras de Ciências são locais nos quais a ciência ganha uma maior visibilidade, pois possibilitam o protagonismo dos educandos ao explorar as suas habilidades, como a investigação, a explicação de fenômenos e a criticidade, além de despertar o interesse dos mesmos pela pesquisa, colaboram na divulgação dos conhecimentos científicos e promovem a integração da comunidade escolar (SILVA et al, 2018). 
Segundo Lippert, Albuquerque e Lima (2019, p.156), o Clube de Ciências é um espaço possível para participação de licenciandos em ações docentes revigoradas, no qual estudantes de cursos de licenciatura podem atuar como monitores de atividades propostas a alunos da Educação Básica.

Para Lenz e Herber (2013, p.69) as Feiras de Ciências contribuem para inserir e despertar nos alunos o interesse pelas Ciências, possibilitando que investiguem sobre problemas locais, regionais, estaduais, enfim permitem que ampliem seus conhecimentos sobre determinado assunto por meio da pesquisa.

No ano de 2018, a Coordenação de Aperfeiçoamento de Pessoal de Nível Superior - CAPES, lançou a chamada pública para o Edital N07/2028 do PIBID, no qual a Universidade Federal do Pampa UNIPAMPA, participou com seus cursos de licenciatura e dentre estes cursos, o Campus Uruguaiana, participou com o subprojeto Ciências da Natureza, contando com 24 bolsistas do Curso Ciências da Natureza - Licenciatura, distribuídos em três escolas campo.

Ao longo de 18 meses, nestas escolas campo, inúmeras foram as ações desenvolvidas, em parceria com as professoras supervisoras e que envolveram toda a comunidade escolar. Dentre estas ações, destaca-se a organização de Clube de Ciências e a realização de Feiras de Ciências em duas escolas campo. Na terceira escola foi realizada uma Feira de Ciências, que não será alvo de discussão no presente trabalho. Diante deste registro, o presente artigo busca refletir sobre a seguinte questão: as Feiras e Clube de Ciências podem ser exemplos de espaços para o letramento científico dos envolvidos?

A partir desta necessidade de reflexão e de análise, o objetivo deste artigo foi analisar a importância das Feiras e Clubes de Ciências enquanto espaços de letramento científico, para alunos, professores supervisores e bolsistas do PIBID Ciências da Natureza - Licenciatura da UNIPAMPA, Campus Uruguaiana.

\section{METODOLOGIA}

Segundo Gil (2008), o presente estudo caracteriza-se por uma pesquisa qualitativa, buscando nos registros dos relatos e das participações dos estudantes (pibidianos) as contribuições destes para o processo de formação nas escolas campo.

Para Gerhardt e Silveira (2009), os pesquisadores que utilizam os métodos qualitativos buscam explicar o porquê das coisas, exprimindo o que convém ser feito, mas não quantificam os valores e as trocas simbólicas nem se submetem à prova de fatos, pois os dados analisados são não-métricos (suscitados e de interação) e se valem de diferentes abordagens.

A pesquisa qualitativa preocupa-se, portanto, com aspectos da realidade que não podem ser quantificados, centrando-se na compreensão e explicação da dinâmica das relações sociais.

Para Minayo (2001), a pesquisa qualitativa trabalha com o universo de significados, motivos, aspirações, crenças, valores e atitudes, o que corresponde a um espaço mais profundo das relações, dos processos e dos fenômenos que não podem ser reduzidos à operacionalização de variáveis.

O desenvolver desta escrita teve base com a vivência dos participantes do Programa Institucional de Bolsas de Iniciação à Docência (PIBID), edital no 7 de 2018, do subprojeto Ciências da Natureza Licenciatura da Universidade Federal do Pampa (UNIPAMPA) Campus Uruguaiana. As atividades 
desenvolvidas ocorreram no município de Uruguaiana no decorrer dos anos de 2018-2019, em duas escolas públicas participantes do PIBID, EMEF Cabo Luis Quevedo que será chamada de Escola A (Feira de Ciências) e EMEF Marília Sanchotene Felice, Escola B (Clube de Ciências).

Após a participação dos licenciandos (pibidianos) nas reuniões de planejamento, com vistas à apreensão da dinâmica escolar e da realização de estudos dirigidos e planejamento de intervenção pedagógica em conjunto com as supervisoras, houve a proposta das Feiras de Ciências (Escola A) e Clube de Ciências (Escola B). Tendo como objetivo reunir os trabalhos realizados pelos educandos dos anos finais do Ensino Fundamental, abrangendo todas as turmas do $6^{\circ}$ ao $9^{\circ}$ ano, dando a estes a condição de protagonistas, do processo de aprendizagem, com o envolvimento direto de 60 alunos, 40 alunos na escola $\mathrm{A}$ e 20 alunos na escola $B$.

\section{RESULTADOS E DISCUSSÃO}

Para a realização dos registros e análises sobre a importância das Feiras e Clubes de Ciências, consideramos os relatos feitos pelos educandos, professores, supervisoras, bolsistas e demais participantes do PIBID Ciências da Natureza.

\subsection{Escola A - Feiras de Ciências}

A proposta da feira de ciências na escola surgiu depois que alguns alunos desfrutaram de aulas no laboratório de ciências da escola. Em uma das aulas sobre o reino Fungi, os pibidianos em conjunto com a professora regente realizaram um experimento sobre o uso do fermento químico e o do fermento biológico. No experimento citado os estudantes conseguiram visualizar a diferença no tempo de atuação de cada fermento, isto foi possível devido a presença de um balão que estava preso em cada tubo de ensaio que continha as misturas de cada um dos fermentos, os discentes que presenciaram ambos os balões encherem, ficaram impressionados com o ocorrido, efetuaram várias perguntas aos pibidianos e a professora.

Segundo Corsini e Araújo (2007) a educação em ciências nos dias de hoje não pode mais se ater estritamente ao contexto formal da sala de aula e às práticas educativas em ambientes não-formais de aprendizagem destacam-se em Feiras de Ciências e Tecnologias, em Museus de Ciências, Parques Ecológicos e ambientes virtuais. Wolinski (2011, p.143) complementa: "[...] A sociedade demandou por ampliações e ressignificações dos espaços de aprendizagem e, a educação apoiada exclusivamente na escola parece já ter deixado de existir, pelo menos nos centros urbanos".

Promover ciências e conseguir envolver a comunidade escolar como um todo se mostra um desafio grandioso, entretanto o uso das feiras de ciências se mostra essencial no momento de divulgar e promover a ciência no contexto escolar, levando a comunidade novos olhares e percepções do fazer ciências, conseguir desmistificar e potencializar o imaginário do aluno, no qual se prende somente ao conteúdo e exemplos dentro de sala de aula.

Porém, com a chegada do PIBID Ciências da Natureza na escola, muitas coisas que foram idealizadas pela gestão da escola, como as feiras de ciências, puderam ser concretizadas nos anos de 2018 e 2019 (Figura 1). Ao promover eventos como feiras de ciências, incentiva-se a investigação e iniciação científica, alia-se a teoria com a prática e potencializa-se a criatividade dos estudantes. 
Figura 1 - Logotipo das Feiras de Ciências da EMEF Cabo Luis Quevedo

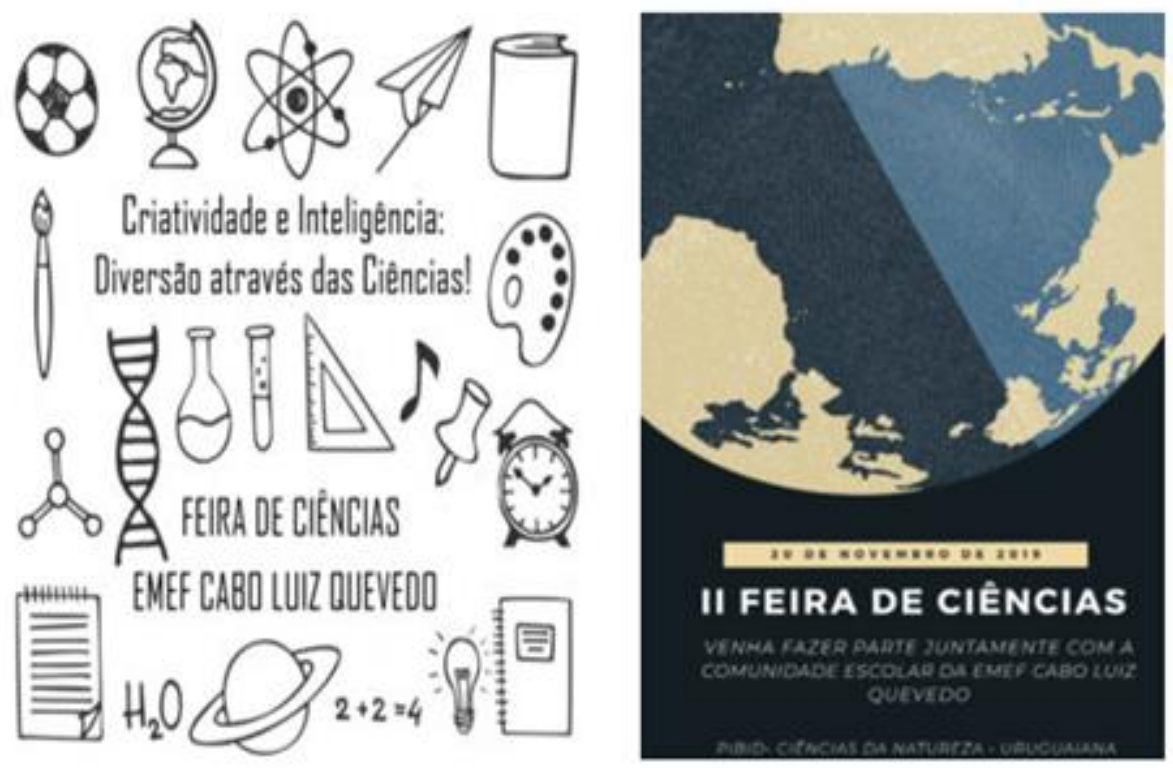

Fonte: produzida pelos pibidianos.

As Feiras de Ciências foram acontecimentos muito esperados pelos alunos, a expectativa para que seus experimentos fossem bem-sucedidos era enorme. $E$ não foram só os alunos que se entusiasmaram com a feira, os discentes também se motivam com a possibilidade de organização do evento, conforme pode ser observado na fala de um dos pibidianos:

Desenvolver projetos na feira de ciências, foi de enorme importância para a minha profissão, pois auxiliando os alunos na execução dos projetos eu pude praticar, atuar na área onde eu vou me formar futuramente nas ciências.

As feiras de ciências vão ao encontro dos documentos oficiais que norteiam a educação, visto que na BNCC, há o seguinte registro:

[...] a área de Ciências da Natureza, por meio de um olhar articulado de diversos campos do saber, precisa assegurar aos alunos do Ensino Fundamental o acesso à diversidade de conhecimentos científicos produzidos ao longo da história, bem como a aproximação gradativa aos principais processos, práticas e procedimentos da investigação científica. Espera-se, desse modo, possibilitar que esses alunos tenham um novo olhar sobre o mundo que os cerca, como também façam escolhas e intervenções conscientes e pautadas nos princípios da sustentabilidade e do bem comum (BRASIL, 2018, p.321).

Sobre a importância das feiras de ciências, Lenz e Herber (2013, p.69) fazem o seguinte registro:

Acreditamos que as Feiras de Ciências contribuem para inserir e despertar nos alunos o interesse pelas Ciências, possibilitando que investiguem sobre problemas locais, regionais, estaduais, enfim permitem que ampliem seus conhecimentos sobre determinado assunto por meio da pesquisa.

\subsection{Circuito Sensorial na $1^{a}$ Feira de Ciências}

Durante a feira de ciências da escola em novembro de 2018, os bolsistas do Pibid da escola organizaram e aplicaram um circuito sensorial com elementos da natureza cujo intuito era potencializar as habilidades cognitivas e sociais através do tato, olfato, paladar e audição. 0 circuito 
contou com elementos como: areia, flores, frutas, folhas secas, pedras pequenas, álcool gel, aromas, etc., que foram distribuídos em caixas de papelão.

Segundo Gonçalves, Mello e Carpes (2016, p.11) "a oficina 'Circuito Sensorial' é uma boa estratégia para fomentar discussões acerca de metodologias de ensino em ciências e da importância de conceitos de fisiologia, tais como a fisiologia sensorial". Oficinas como esta, buscam aproximar o professor de novos métodos que possam ser utilizados em sala de aula e facilitam a compreensão da importância e relativa simplicidade que pode ser adotada para se trabalhar temas importantes na área de ciências.

Os participantes do circuito recebiam as seguintes orientações: em um ambiente com pouca luminosidade, foram vendados e orientados a retirarem seus calçados. Com uma música instrumental ao fundo, foram conduzidos pelos bolsistas por um "caminho tátil" com os elementos citados. Durante o projeto, eram interpelados a falarem sobre as experiências físicas, motoras, cognitivas e sensoriais que estavam sentindo (Figura 2).

Uma das bolsistas que participaram da organização e aplicação do Circuito Sensorial relatou:

Esta atividade desenvolvida pelos Pibidianos e da qual pude participar, me fez refletir sobre a importância da questão da inclusão nas escolas e universidades.

Figura 2 - Imagem dos bolsistas do PIBID durante o circuito sensorial

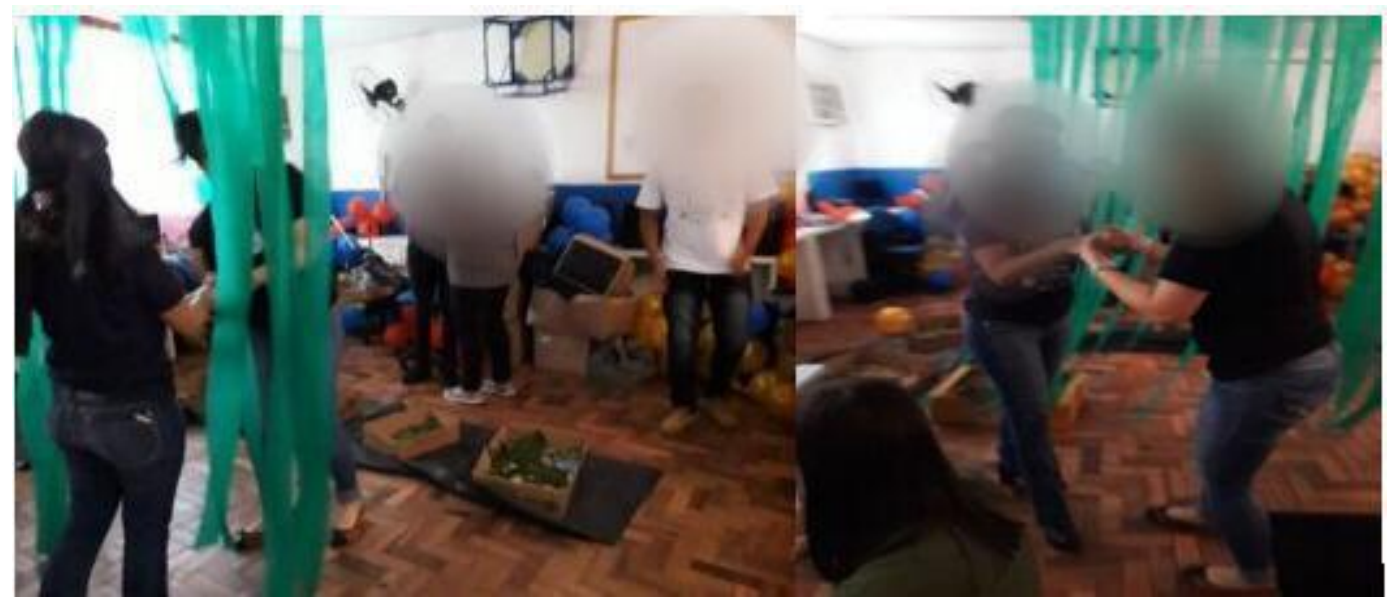

Fonte: produzida pelos pibidianos.

\subsection{Carta Celeste Interativa na $1^{\text {a }}$ Feira de Ciências}

Segundo Justiniano e Botelho (2016, p. e4311-2), "uma carta celeste é um mapa do céu. Esse mapa é utilizado para identificar e localizar os objetos astronômicos, principalmente planetas, constelações e estrelas".

A Carta Celeste foi desenvolvida pelos alunos, sob a orientação dos bolsistas do PIBID. Inicialmente houve a ampliação da Carta Celeste em papel A4 para uma lona preta de 4, 5 x 3,8 m. As estrelas foram representadas através de tampas de garrafas e base de isopor. Sua representação geométrica foi através de barbante, para ter uma melhor compreensão e visualização por parte do observador dos grupos estelares. Com o objetivo de privilegiar o lúdico, foi confeccionado um foguete usado como cabine para fotos (Figura 3). Ainda segundo Justiniano e Botelho (2016, p. e4311-7), "Como quase sempre acontece quando os alunos têm a oportunidade de participar de uma atividade diferente das tradicionais, a resposta é gratificante para o professor". 
Figura 3 - Imagens da organização e produção da Carta Celeste interativa

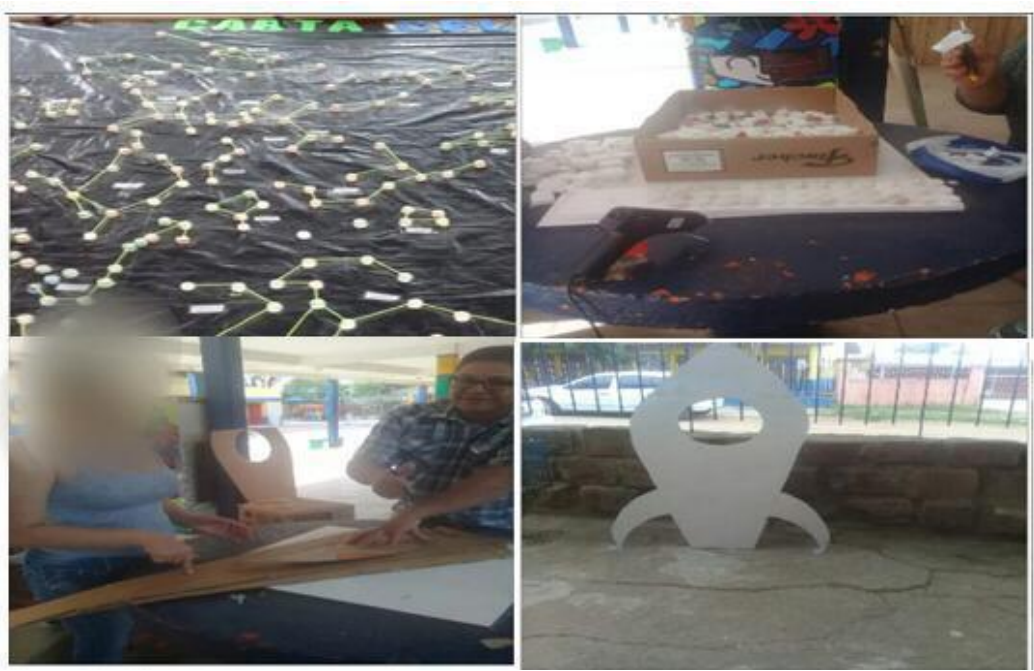

Fonte: produzida pelos pibidianos.

A II Feira de Ciências da escola Cabo Luiz Quevedo foi organizada desde outubro/2019 e tinha como objetivo divulgar os conhecimentos desenvolvidos no decorrer do ano letivo e fomentar nos/nas estudantes o conhecimento e a experimentação científica, além de exercitar a oralidade, a escrita científica e a pesquisa, uma vez que para realizar os experimentos os/as estudantes deveriam pesquisar sobre os fenômenos relacionados e fazer um breve resumo do seu trabalho.

Os estudantes demonstraram-se felizes e orgulhosos com os seus trabalhos, apresentando de forma clara e didática, para que todos as pessoas que fossem prestigiar o evento conseguissem entender o objetivo dos experimentos. Os bolsistas do PIBID auxiliaram os/as jovens cientistas desde a organização dos experimentos até o momento das suas apresentações, para que dessa forma os mesmos se sentissem confiantes.

Depoimento de uma bolsista:

Participar da organização destes momentos de aprendizagem, incentivando, ensinando e aprendendo com o processo do desenvolvimento dos experimentos, muito contribui com a formação docente, pois como futuro professor você consegue visualizar o crescimento e o aprendizado dos alunos da educação básica.

\subsection{Exposição dos "Lapbooks" na $2^{\mathrm{a}}$ Feira de Ciências: uma ferramenta pedagógica apresentada pelo PIBID}

Segundo Schmidt (2013) os Lapbooks são caracterizados como pastas, fichário com recortes, minilivros e dobraduras feitas com papéis coloridos, o principal objetivo é fazer o aluno compreender o conteúdo de forma mais dinâmica e objetiva.

Sobre os Lapbooks, Benites e Mello (2019, p. 17) registram:

Esse artefato pedagógico permite conexão maior do estudante com o conteúdo, pois aquilo que é visto em aula é sintetizado em um material concreto. Dessa forma, a aprendizagem se torna mais significativa, agradável, mais importante, divertida para o educando. Possibilitar momentos de prazer aliado à aprendizagem faz parte do papel fundamental da escola.

Os alunos construíram "lapbooks" com o auxílio dos bolsistas do PIBID sobre os "artrópodes". Essa ferramenta pedagógica foi uma proposta trazida pelos bolsistas do PIBID para servir como material 
de estudo e aplicação de conhecimento, o material é interativo e para a sua construção foi necessário usar a imaginação e criatividade (Figura 4). Para a construção do "lapbook" os estudantes pesquisaram sobre o tema, separando conceitos que os mesmos consideram importantes para colocar no material, dessa forma o aprendizado torna-se muito mais construtivo e interessante.

Segundo uma das bolsistas que orientou a construção desses artefatos pedagógicos:

Os "lapbooks" foram expostos na Feira de Ciências, a fim de demonstrar à comunidade escolar que é possivel ampliar as formas de aplicar o conhecimento e que podem ser utilizados com estudantes de qualquer faixa etária e sobre qualquer assunto. Os trabalhos chamaram muita atenção, pois ficaram com uma estética muito bonita e chamativa, despertando assim o interesse das pessoas que estavam prestigiando a feira.

Figura 4 - Imagens dos Lapbooks que foram expostos durante a II Feira de Ciências

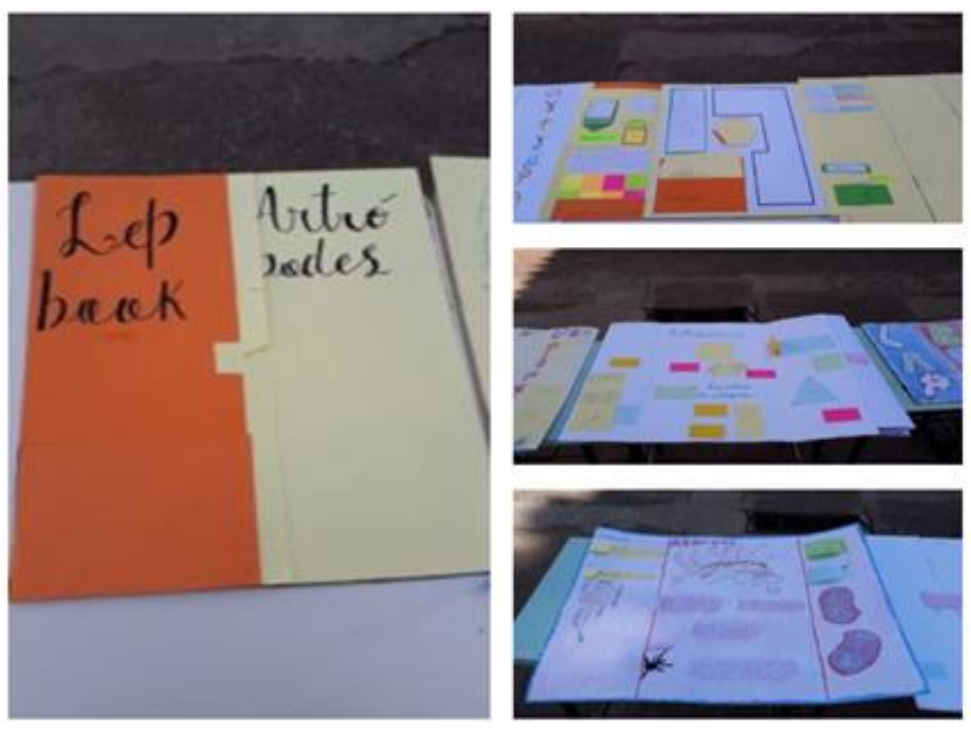

Fonte: produzida pelos pibidianos.

Acreditamos que todos os registros que foram feitos podem ser considerados exemplos de processos de ensino e aprendizagem em espaços não formais, que se bem planejados e executados, com o protagonismo dos alunos configura-se um espaço de Letramento Científico. O Letramento científico é um conceito amplo que tem evoluído desde a primeira utilização do termo no final dos anos 1950, utilizado para descrever a compreensão da ciência e as suas aplicações na sociedade (GOMES, 2015, p.33).

De acordo com a disposição do Programa Internacional de Avaliação de Alunos (Pisa), (PISA, 2015), a definição de letramento científico é apresentada por:

Letramento Científico é a capacidade de se envolver com as questões relacionadas com a ciência e com a ideia da ciência, como um cidadão reflexivo. Uma pessoa letrada cientificamente, portanto, está disposta a participar em discurso fundamentado sobre ciência e tecnologia, o que exige as competências para: 1. Explicar fenômenos cientificamente: Reconhecer, oferecer e avaliar explicações para fenômenos naturais e tecnológicos. 2. Avaliar e planejar investigações científicas: descrever e avaliar investigações científicas e propor formas de abordar questões cientificamente. 3. Interpretar dados e evidências cientificamente: analisar e avaliar os dados, afirmações e argumentos, tirando conclusões científicas apropriadas (PISA, 2015, p. 7). 
Portanto, a utilização da compreensão científica, em prol da sociedade. Para isso não basta apenas o aporte teórico, pois o conhecimento discutido precisa de apropriação por parte dos alunos, para que de fato a sociedade ganhe em termos de conhecimento e aplicação.

\subsection{Escola B - Clube de Ciências}

A ideia do Clube de Ciências surgiu na necessidade de levar aos alunos dos anos finais do Ensino Fundamental o alinhamento da teoria da sala de aula com a prática experimental do laboratório, oferecendo às discentes possibilidades de ampliar seu olhar científico em relação às suas vivências do dia a dia. A escola dispõe de um laboratório de ciências amplo, porém não possui muitos exemplares de materiais para uso em experimentos, fator limitante para a realização de determinadas atividades.

Segundo Garcia Lippert, Fogaça Albuquerque e Rosário Lima (2019, p.158):

Os Clubes de Ciências são definidos como espaços pedagógicos com possibilidade de estudos científicos numa perspectiva de construção/produção de conhecimentos, apresentando forte integração com a comunidade e estando seus participantes envolvidos em clima de cooperação e solidariedade. [...] os Clubes têm em comum o fato de serem um espaço para os estudantes exporem diferentes interesses científicos, estudarem novos assuntos de acordo com as suas expectativas e praticarem a pesquisa.

Para Dos Santos et al (2010, p.3) a concepção do clube de ciências mudou:

[...] onde antes visava atender os avanços tecnológicos, agora tem como objetivo tornar o ensino de ciências significativo dando sentido a ele e fazendo ligação da teoria com prática através de processos de investigação, dando ênfase no cotidiano na realidade local e enfoque não só a conteúdo de cunho científico, mas interagindo com o social.

Na Escola B o Clube de Ciências foi conduzido e organizado por um grupo de cinco bolsistas PIBID do curso de licenciatura em Ciências da Natureza da Universidade Federal do Pampa/UNIPAMPA campus Uruguaiana, junto com a professora de ciências dos anos finais responsável pelo grupo de bolsistas e com o coordenador do PIBID.

A organização do Clube de Ciências ocorreu em dois momentos: pré-clube, subdividido em duas etapas, com a realização de um período de divulgação na escola e um período de inscrição, no qual se solicitou a produção de um pequeno texto justificando a motivação para participar do Clube de Ciências, que serviu de premissa no processo de seleção dos 15 alunos participantes, advindos do $6^{\circ}$ (sexto) ao $9^{\circ}$ (nono) ano.

Após a seleção dos participantes, o Clube de Ciências iniciou suas atividades, desenvolvendo discussões que possibilitasse um viés inovador dentro de suas potencialidades e que servisse de suporte enquanto espaço de extensão dos conteúdos programáticos de sala de aula.

Após os primeiros encontros do clube, os alunos demonstraram grande curiosidade em compreender os processos físicos, químicos e biológicos ao seu redor, tendo o clube um papel de suma importância em sanar suas dúvidas no campo científico desde os conceitos mais básicos aos mais complexos e imperceptíveis aos olhos destes alunos, buscando aprofundar e aperfeiçoar seus conhecimentos previamente adquiridos em sala de aula. 
A figura 5, registra o primeiro dia de reunião do Clube de Ciências, onde foi proposto aos alunos a construção de um cartaz que representasse "O que é ciências?", no qual foi possível observar o trabalho em grupo e o envolvimento dos alunos em sistematizar seus conhecimentos dentro da temática de ciências.

Essas indagações iniciais se fazem necessário para que os alunos possam entender por que e para quê ensinar ciências. Pois segundo Viecheneski e Carletto (2013, p.214):

[...] se por um lado é reconhecida a importância da democratização dos conhecimentos científicos e o papel da escola na disseminação da cultura científica, por outro, as pesquisas em educação em ciências têm revelado uma situação preocupante no que se refere ao ensino dessa área, sobretudo no Ensino Fundamental.

Pois a partir do momento que os alunos entendam o importante papel do ensino de ciências, para a promoção da cidadania e para o desenvolvimento da sociedade, estes tendem a se tornar mais ativos, proativos em relação ao ensino e buscam por modelos que sejam significativos em suas vidas.

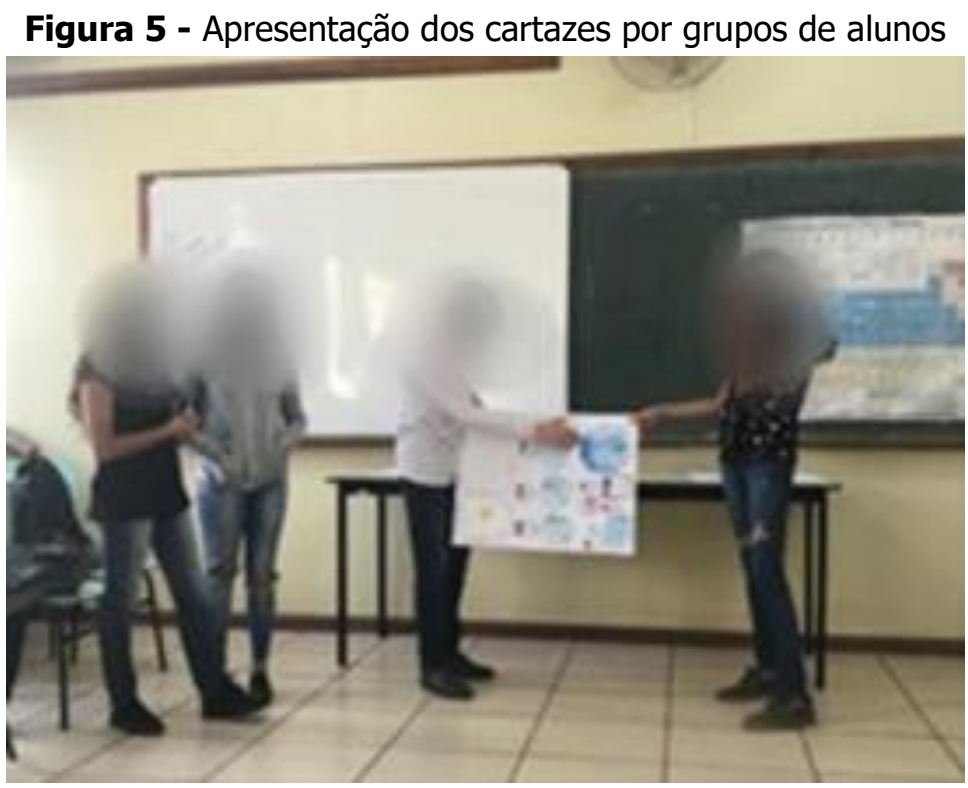

Fonte: produzida pelos pibidianos.

\subsection{Suco de repolho roxo como indicador de $\mathrm{PH}$}

Segundo Fogaça (sd) os indicadores ácido-base são substâncias que mudam de cor, informando se o meio está ácido ou básico. Existem indicadores sintéticos, como a fenolftaleína, o azul de bromotimol, o papel de tornassol e o alaranjado de metila. Porém, existem também algumas substâncias presentes em vegetais que funcionam como indicadores ácido-base naturais.

Geralmente, essas substâncias estão presentes em frutas, verduras, folhas e flores bem coloridas, tais como a beterraba, jabuticaba, uva, amoras e nas folhas do repolho roxo, pois todos estes vegetais são ricos em Antocianinas e seus extratos servem como indicadores de Ph.

$\mathrm{Na}$ figura 6, se observa o resultado da oficina sobre as diferenças de $\mathrm{pH}$, de diferentes produtos desde o mais "básico" ao mais "ácido", medidos através do uso do suco extraído pela fervura das folhas do repolho roxo, reproduzindo um arco-íris das cores e suas respectivas características para tal tonalidade final. 
$\mathrm{Na}$ atividade do $\mathrm{pH}$, pode-se registrar a curiosidade dos alunos e o despertar para a ciências, visto que alunos foram protagonistas e puderam manusear e desenvolver todo o processo experimental, indagando os bolsistas sobre os acontecimentos observados.

Figura 6 - Mudanças de cores das substâncias em função do pH

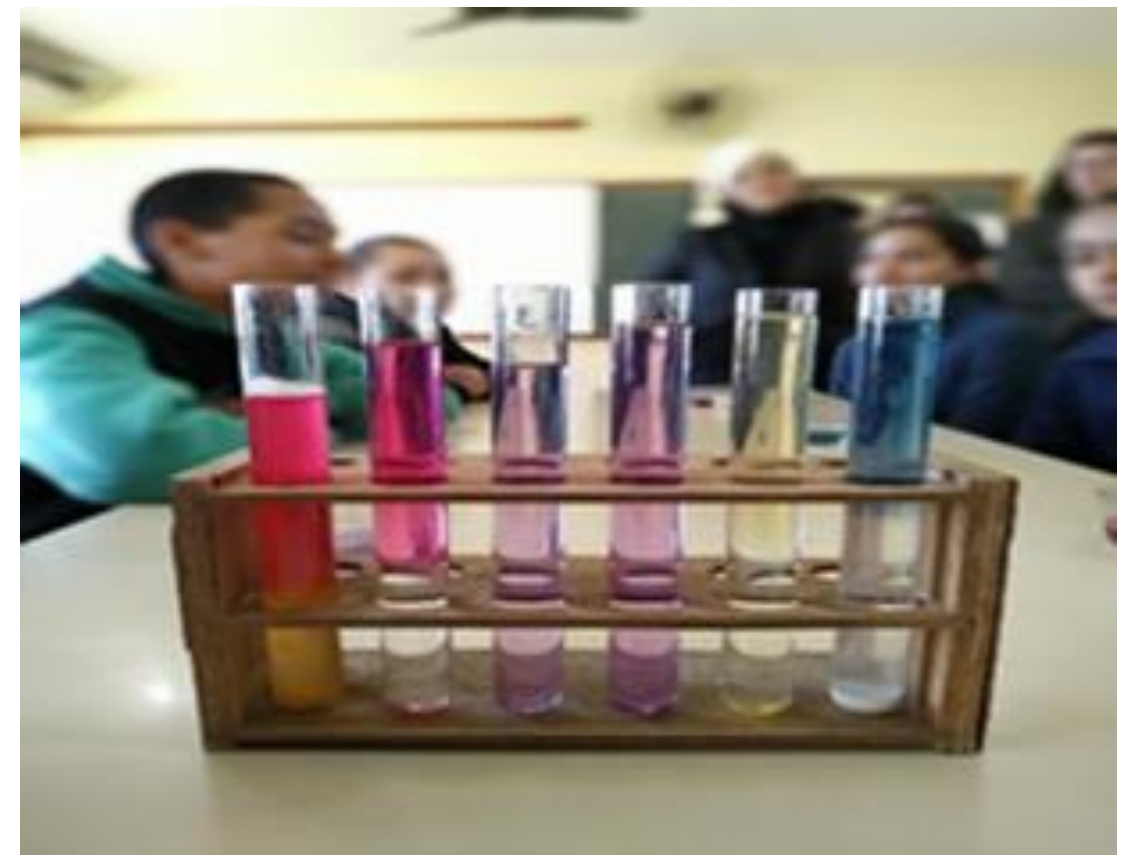

Fonte: produzida pelos pibidianos.

\subsection{Experimento de extração do DNA da banana}

Outro assunto abordado no Clube de Ciências foi o estudo sobre o ácido desoxirribonucleico (DNA): sua estrutura, função, composição, curiosidades e fatos históricos, como o descobrimento e a fotografia realizada pela cientista britânica Rosalind Franklin (1920-958). Importante tratar dos assuntos históricos que envolve a ciência, e particularmente os eventos científicos sobre a descoberto da estrutura do DNA, visto que há uma certa discussão sobre a falta de citações sobre a importância da pesquisa de Franklin (imagens da difração de raios-X do DNA), que levou à descoberta da dupla hélice do DNA por James Watson, Francis Crick e que segundo alguns historiadores, não deram o crédito ao trabalho da referida pesquisadora.

Após os estudos teóricos chegou o momento de realizar uma atividade prática, para que os alunos tivessem a oportunidade de participar da prática de extração do DNA da banana.

O objetivo deste experimento foi demonstrar que é possível utilizar um vegetal como matéria-prima para discutir a presença do DNA em todos os seres vivos (Figura 7). De maneira simplificada, os materiais utilizados foram banana, saco plástico, água, sal, detergente de louça neutro e álcool etílico gelado. Depois de todos os procedimentos do experimento, o filamento de DNA formou um precipitado, com um aspecto gelatinoso, ou seja, o DNA da banana condensado. A realização de aulas práticas como essa oportunizaram a experiência, a discussão sobre o método científico, com a atuação ativa dos alunos no processo ensino-aprendizagem em ciências. 
Figura 7 - Experimento sobre extração do DNA da Banana

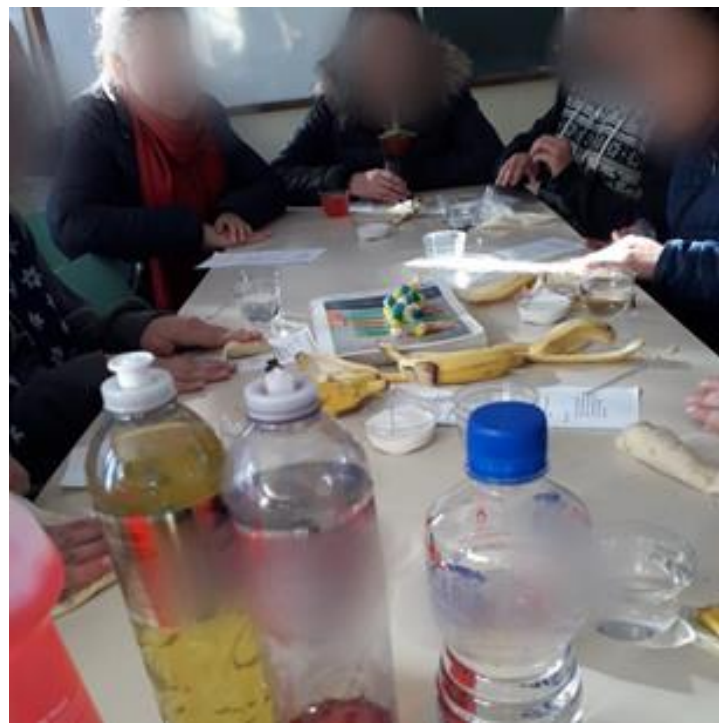

Fonte: produzida pelos pibidianos.

O ensinar ciências se mostra um desafio e ao mesmo tempo, um vasto campo de trabalho e experimentação, visto que há uma imensa curiosidade da natureza humana em descobrir cada vez um novo olhar sobre os acontecimentos físicos, químicos e biológicos de seu cotidiano. Com o Clube de Ciências, tivemos a oportunidade de desenvolver espaços e discussões que possibilitaram a imersão dos alunos em um mundo científico de descobertas. Garcia Lippert, Fogaça Albuquerque e Rosário Lima (2019, p.157), fazem uma crítica ao ensino atual, pois registram que: "[...]observando o panorama atual do ensino de ciências, se percebe o "conteudismo" como característica significativamente presente no cotidiano de professores que, ainda expressando resquícios da sua formação, preocupam-se em "vencer conteúdos"'!".

Tendo em vista essa perspectiva engessada no ensino e ao mesmo tempo, o quanto os alunos anseiam por novas metodologias de ensino e aprendizagem, percebe-se o quão cheio de lacunas se torna o ensinar ciências, sem ao menos aprofundar quaisquer das discussões com viés científico, deixando de apresentar aos alunos tais possibilidades. Ao desenvolver o Clube e a Feira de Ciências, espaços de desenvolvimento científico na rede básica de ensino, se permite a discussão de temáticas científicas, de forma mais aprofundada, alinhando os conhecimentos previamente adquiridos em sala de aula, em algo "palpável" e de fácil entendimento, desmistificando a linguagem científica.

Na perspectiva dos Pibidianos, esses espaços de letramento científico, além de promover uma socialização interativa, contribui para a aplicação do ensino de ciências de uma forma que se obtenha o conhecimento objetivado, tornando o aluno protagonista de sua aprendizagem, onde se associa os conhecimentos teóricos e práticos.

\section{CONSIDERAÇÕES FINAIS}

A organização das Feiras de Ciências, nos anos de 2018 e 2019 e do Clube de Ciências nas duas escolas campo proporcionaram aos bolsistas do PIBID Ciências da Natureza, momentos de grande aprendizado, contribuindo com o processo de formação inicial destes licenciandos.

Por outro lado, a inserção dos bolsistas nas escolas e as ações desenvolvidas, provocou um movimento positivo, que possibilitou aos envolvidos, momentos de reflexão e de ajustes, pois 
despertou nos alunos e professores a vontade de fazer diferente, de se lançar para novas possibilidades, ou seja, o PIBID pode ser considerado uma via de mão dupla, onde todos podem transitar e se beneficiar enquanto espaço de formação, inicial e continuada.

As Feiras de Ciências e o Clube de Ciências contribuíram com o processo de formação, de protagonismo e de letramento científico. Diante dos relatos, do que foi discutido e planejado para o ensino de ciências, de fato o projeto desenvolveu a capacidade dos pibidianos em organizar Feiras e Clubes de Ciências, articulando estes espaços como recurso potencial para o desenvolvimento do letramento científico na Educação Básica.

\section{REFERÊNCIAS}

ALVES, Alexandra Camargo; PEREIRA, Andréia Regina; LOPES, Roseli de Deus; FICHEMAN, Irene Karaguilla. Projetos de ciências e engenharia na educação básica: estímulo por meio de feiras de ciências. In: Simpósio Brasileiro de Informática em Educação (SBIE), 2004, Anais. Manaus: UFAM, 2004. p. 47-9. Disponível em: http://br-ie.org/pub/index.php/sbie/article/view/372. Acesso em: 09 ago. 2020.

BRASIL. Base Nacional Comum Curricular. Brasília: MEC, 2018. Disponível em: http://basenacionalcomum.mec.gov.br/images/BNCC_20dez_site.pdf. Acesso em: 10 ago. 2020.

BRASIL. Referenciais para a formação de professores. 2. ed. Brasília: Secretaria de Educação Fundamenta 2002.

Disponível

em:

http://portal.mec.gov.br/index.php?option=com_docman\&view=download\&alias=48631-

reformprof1\&category_slug=documentos-pdf\&Itemid=30192. Acesso em: 10 ago. 2020.

BRASIL. Secretaria de Educação Fundamental. Parâmetros curriculares nacionais: Ciências Naturais/Secretaria de Educação Fundamental. Brasília: MEC /SEF, p. 28, 1998. Disponível em: rtal.mec.govhttp://po.br/seb/arquivos/pdf/introducao.pdf. Acesso em: 05 jul. 2020.

CHASSOT, Attico. Alfabetização Científica: uma possibilidade para inclusão social. Revista brasileira de educação, Rio de Janeiro, v. 2, n. 22, p. 89-100, 2003.

CHASSOT, Attico. Educação consciência (2. ed). Santa Cruz do Sul: EDUNISC, 2007.

FOGAÇA, Jennifer Rocha Vargas. Indicador ácido-base com repolho roxo. Manual da Química [online]. Disponível em https://www.manualdaquimica.com/experimentos-quimica/indicador-acidobase-com-repolho-roxo.htm. Acesso em: 09 ago. 2020.

GERHARDT, Tatiana Engel; SILVEIRA, Denise Tolfo (Org.) Métodos de pesquisa. Porto Alegre: Editora da UFRGS, 2009.

GIL, Antonio Carlos. Como elaborar projetos de pesquisa. 4. ed. São Paulo: Atlas, 2008. Disponível em: http://www.uece.br/nucleodelinguasitaperi/dmdocuments/gil_como_elaborar_projeto_de_pesquisa. pdf. Acesso em: 06 ago. 2020.

GOMES, Anderson (org.) Letramento Científico: um indicador para o Brasil. São Paulo: Instituto Abramundo. 2015.

GONÇALVES, Rithiele; BILLIG MELLO, Elena Maria; MELLO-CARPES, Pâmela Billig. Oficina "Circuito sensorial" como metodologia utilizada na formação continuada de professores de ciências - um relato de experiência. Revista Ciência em Extensão, v. 12, n. 1, p. 6-13, 2016. 
JUSTINIANO, Artur e Botelho, RafaelConstrução de uma carta celeste: Um recurso didático para o ensino de Astronomia nas aulas de Física. Revista Brasileira de Ensino de Física [online], v. 38, n. 4, 2016. Disponível em: https://doi.org/10.1590/1806-9126-RBEF-2016-0131. Acesso em: 07 jul. 2021.

LENZ, Ângela Maria Schoor; HERBER, Jane. Feira de Ciências: um projeto de iniciação à pesquisa. Revista Destaques Acadêmicos, v. 5, n. 5, 2013.

LIPPERT, Beatriz Garcia; ALBUQUERQUE, Nathália Fogaça; DO LIMA, Valderez Marina do Rosário. Clube de Ciências como um Espaço de Formação: Concepções de Monitores sobre Ensinar Ciências. Práxis Educacional, Bahia, v. 15, n. 32, p. 155-173, 2019.

MANCUSO, Ronaldo. Feiras de ciências: produção estudantil, avaliação, consequências. Contexto Educativo. Revista digital de Educación y Nuevas Tecnologias, n. 6, 2000. [online] Disponível em: http://contexto-educativo.com.ar/2000/4/nota-7.htm. Acesso em: 07 Set. 2020.

MINAYO, Maria Cecília de Souza. (Org.). Pesquisa social: teoria, método e criatividade. Petrópolis: Vozes, 2001.

PISA 2015. OECD PISA 2015: Programa Internacional de Avaliação de Estudantes. Matriz de Avaliação de Ciências. Resumo do Documento: Pisa 2015 Science framework (2013). Disponível em: https://download.inep.gov.br/acoes_internacionais/pisa/marcos_referenciais/2015/matriz_de_cienci as_PISA_2015.pdf. Acesso em: 07 jun. 2020.

SANTOS, Juliano dos; CATÃO, Ruth Kellen. Estruturação e consolidação de Clubes de Ciências em escolas públicas do Litoral do Paraná. In: II Simpósio Nacional de Ensino de Ciência e Tecnologia. Out. 2010, Ponta Grossa. Anais. Ponta Grossa: SINECT, p. 1-14, 2010.

SASSERON, Lúcia Helena; CARVALHO, Anna Maria Pessoa de. Alfabetização Científica: Uma Revisão Bibliográfica. Investigações em Ensino de Ciências, v. 16, n. 1, p. 59-77, 2011.

SASSERON, Lúcia. Helena. Alfabetização científica e documentos oficiais brasileiros: um diálogo na estruturação do ensino de física. Carvalho, Anna Maria Pessoa de; ELIO, Carlos Ricardo; SASSERON, Lúcia Helena; ABIB, Maria Lúcia Vital dos Santos; PIETROCOLO, Maurício (Org.). Ensino de Física. São Paulo: Cengage Learning, 2010.

SAVIANI, Dermeval. Escola e democracia. 24. ed. São Paulo: Cortez, 1991.

SILVA, Cristiane Reis Barcelos. Letramento científico no âmbito do programa de iniciação à docência (PIBID): uma análise de produção científica na área de ensino de ciências. 2016. 121p. Dissertação (Mestrado Profissional) Universidade Federal de Lavras, 2016.

SILVA, Nayane de Oliveira; ALMEIDA, Cristina Guilherme de; LIMA, Débora Raquel Sarmento. Feira de Ciências: Uma estratégia para promover a interdisciplinaridade. Revista Destaques Acadêmicos, Lajeado, v. 10, n. 3, 2018.

VIECHENESKI, Juliana Pinto; CARLETTO, Marcia. Por que e para quê ensinar ciências para crianças. Revista Brasileira de Ensino de Ciência e Tecnologia, v. 6, n. 2, p. 213-227, 2013.

WOLINSKI, Alan Eduardo; AIRES, Joanes; GIOPPO, Christiane; GUIMARÃES, Orlliney. Por que foi mesmo que a gente foi lá? Uma investigação sobre os objetivos dos professores ao visitar o Parque da Ciência Newton Freire-Maia. Química Nova na Escola, v. 33, n. 3, p. 142-152, 2011.

Submissão: 08/07/2021

Aceito: 31/08/2021 